\title{
Defining the starvation potential and the influence on RNA/DNA ratios in horse mackerel (Trachurus mediterraneus) larvae
}

\author{
Ilhan Yandi • Ilhan Altinok
}

Received: 15 July 2014/Revised: 16 September 2014/Accepted: 24 September 2014/Published online: 5 October 2014

(c) Springer-Verlag Berlin Heidelberg and AWI 2014

\begin{abstract}
Larval survival potentially affects recruitment strongly. Variability in larval growth rates, primarily caused by variable nutritional situations, is one of the factors that can influence larval survival rates. RNA/DNA ratio as well as protein content was analyzed in wild-caught laboratory-grown and in wild-caught horse mackerel Trachurus mediterraneus in relation to feeding and starvation. For this purpose, field-caught genoblast eggs were incubated and the hatched larvae were reared under different feeding regimes: fed control, unfed control, starved either for 1, 2 or 3 days, on feeding restrictions. The whole-body RNA/DNA ratio and the daily protein growth rate were individually analyzed. In all larvae eye pigmentation, mouth opening and subsequently first feeding started on the third day after hatching. All larvae in the unfed group died on day 8. The survival rate during the first 3 days in delayed feeding groups was higher than that of the unfed group. Overall, growth curves from feeding-delayed larvae indicated that fish fed after up to 3 days starvation were capable of complete recovery with the critical RNA/DNA ratio of $1.05 \pm 0.08$. According to this value, approximately $10 \%$ of the field-caught larvae were starving. Therefore, the RNA/DNA ratio is an easy tool to assess the nutritional status in horse mackerel larvae caught in the field with a high precision rate.
\end{abstract}

Communicated by A. Malzahn.

I. Yandi · I. Altinok ( $\square)$

Department of Fisheries Technology Engineering, Faculty of

Marine Science, Karadeniz Technical University,

61530 Surmene, Trabzon, Turkey

e-mail: ialtinok@gmail.com
Keywords Marine larvae $\cdot$ RNA/DNA ratio $\cdot$ Protein content $\cdot$ Starvation $\cdot$ Nucleic acids

\section{Introduction}

The stocks of horse mackerel (Trachurus mediterraneus) one of the most important economic pelagic species in the Black Sea have annual fluctuations (TUIK 2010). Similarly, pelagic fish stocks such as anchovy, sardine, sprat and bluefin tuna face considerably significant fluctuations worldwide. There are many biotic (feeding success, predation, disease) and abiotic (pollution, water temperature, light, hydrodynamics) factors that affect final recruitment and fishery fluctuations. Prey availability and predation are considered to be the most important factors that drive fluctuations in larval survival (Houde 1978; Kono et al. 2003; Nunn et al. 2007).

Most of commercially important marine fish species spawn pelagic eggs that hatch into underdeveloped larvae whose energy source is of maternal origin (yolk sac and/or oil globules) until they develop the morphological, behavioral and physiological sufficiency that allow them to capture external planktonic food. Important events during the shift from endogenous to exogenous feeding are the opening of the mouth and the development of a functional digestive system (Alemany 2003). The early larval period is considerably critical for further survival. When the opening of the mouth and anus occurs, the yolk sac is completely or almost exhausted (Yufera and Darias 2007); therefore, larvae must rely on maternal-origin energy sources to be able to attain external food, before being physiologically exhausted. Otherwise, lack of external food will lead to a decrease in nutritional condition reaching critical starvation levels. Afterward, even if there is plenty 
of food around, larvae are unable to recover, a status known as point of no return. Larvae in poor nutritional status are less efficient at swimming, foraging and feeding (Amara and Galois 2004). At this point, prey availability has to be sufficient. It is influenced by both biological production (Cushing 1974, 1990) and hydrological processes, which potentially increase encounter rates (Cury and Roy 1989; Lasker 1978; Sinclair 1988). It could be shown that slow growing larvae are selectively removed by predators (Takasuka et al. 2003). Therefore, nutritional status of larvae and juveniles is among the important factor for their survival (Tanaka et al. 2008).

Starving larvae are more vulnerable to predation, disease and unfavorable environmental conditions. During optimal conditions, larvae develop at fast rates until they reach the juvenile stage and they are more resistant to starving. However, the factors determining final larval survival, and probably recruitment, are multiple and interact in a highly complex way (Alemany 2003). The proportion of starving larvae at sea can be estimated by diagnosing the nutritional status of the captured individuals. To examine nutritional status of larvae, most reliable methods are the indices based on nucleic acids, mainly RNA/DNA (Chicharo and Chicharo 2008). In recent years, RNA/DNA has been widely used to determine the nutritional status of marine larvae (Chicharo et al. 2001; Kono et al. 2003; Fonseca et al. 2006; Tanaka et al. 2008, etc.). In the present study, fluorometric methods were used to analyze nucleic acids and protein from individual fish larvae. The aims of the current experiment were to investigate the survival rates, number of tolerated starved days for complete recovery of horse mackerel that were hatched from field-caught genoblast eggs and to assess the nutritional status of field-caught larvae.

\section{Materials and methods}

Field study

Horse mackerel eggs and larvae samplings were carried out at dawn under favorable weather and sea conditions from June to September 2010 on Camburnu coast (a known nursery area) of the Black Sea $\left(40^{\circ} 55^{\prime} 04^{\prime \prime} \mathrm{N}, 40^{\circ} 10^{\prime} 41^{\prime \prime} \mathrm{E}\right)$. Eggs and larvae were collected around the sampling station by horizontal towing of Hensen net at the speed of 1.5-2 knots.

Field collections of genoblast eggs

Hensen-type plankton net with $2.5 \mathrm{~m}$ length, $0.5 \mathrm{~m}$ mouth diameter and $500 \mu \mathrm{m}$ mesh size and $500 \mathrm{~mL}$ collector capacity was designed for egg collection. In order to prevent catching undesired material, a fish net with $1 \mathrm{~cm}$ mesh size was mounted on the net mouth. Hensen net was mounted broadside of the research vessel in order to provide more effective sampling. Eggs were collected both on the water surface and within $50 \mathrm{~cm}$ of the surface for 10 min. Samples within net were transferred to 1-L plastic holding containers and transferred to the laboratory within $2 \mathrm{~h}$ after sampling.

\section{Field collecting of larvae}

Another Hensen net was designed for larvae collection; this plankton net was $3 \mathrm{~m}$ length, $0.65 \mathrm{~m}$ mouth diameter and $300 \mu \mathrm{m}$ mesh size with $500 \mathrm{~mL}$ collector. Towing technique was the same as egg collection except for towing time (5 min). Condensed materials were placed into the styrofoam box containing ice and transferred to laboratory within $1.5 \mathrm{~h}$. Horse mackerel larvae were selected under the microscopy (cold light source and icy ground, according to Dekhnik 1973; Russell 1976). Larvae were individually photographed for notochord length and transferred into $0.5-\mathrm{mL}$ polypropylene PCR tubes and marked then immediately stored at $-80{ }^{\circ} \mathrm{C}$ until analysis.

\section{Fish eggs and hatching}

The samples were filtered using 1,000 and $500 \mu \mathrm{m}$ size filter equipment, respectively, and the filtered samples were then transferred into the petri dishes. Eggs were sorted under a stereo microscope. Only buoyant eggs were received based on their species (according to Dekhnik 1973; Russell 1976), and they were hatched in 1 liter of glass beakers with stocking density of 2,000 larvae per liter. Slight aeration was applied by using seawater resistant wooden aerator to ensure effective hatching. After hatching, the larvae were also examined to determine whether they were horse mackerel or not.

Experimental design

Hatched larvae were transferred into $80-\mathrm{mL}$ black wall and white bottom plastic rearing containers which contained filtered $(10 \mu \mathrm{m})$ and UV-treated seawater. Chicken egg white was added to each experimental container for a final concentration of $60 \mu \mathrm{L} / \mathrm{L}$ (Yandi and Altinok 2012), and this application was continued during incubation and up to 3 days after hatching (DAH). Larvae were fed with smalltype rotifer Brachionus rotundiformis, at a density of 15 individuals per milliliter, and Nannochloropsis oculata $\left(3-5 \times 10^{5}\right.$ cells $\left./ \mathrm{ml}\right)$ were added into rearing media both nourishment for rotifer and assuring natural ambient for rearing larvae. Solid plastic rearing containers that are suitable to monitor larvae under stereo microscope were 
used, and dead larvae were collected at 24-h intervals. Therefore, possible mistakes related to counting of dead larvae were eliminated. Number of larvae transferred into each experimental container is shown in Table 1. A 2,000 lx fluorescent light source, which has equal illumination to sunlight, was mounted $60 \mathrm{~cm}$ above the water surface. The natural seasonal photoperiod was used (16:8 h; light: dark) by using automatic timer. Starvation days and number of elapsed days were counted as 0 for the first-feeding day (eye pigmentation and mouth opening as an index). Five different feeding regimes and their triplicates were conducted: (I) fed constantly beginning from the first-feeding day (FC, fed control); (II) fed after being starved for 1 day from the first-feeding day (1 DF); (III) starved for 2 days (2 DF); (IV) starved for 3 days (3 DF); and (V) unfed constantly (UC, unfed control). Dead larvae were removed by glass pipette and counted from each container under microscopy on each day. Settled organic waste, dead rotifer and microalgae that sank to the bottom of the rearing container were daily removed by siphoning while one-third of the rearing water was exchanged. During the experiment, water temperature and salinity were $21 \pm 0.3{ }^{\circ} \mathrm{C}$ and $17.3 \pm 0.2 \%$, respectively.

\section{Notochord length}

Sampled larvae were photographed with the reference distance of a millimetric ruler connected with lamella under microscopy and then measured by using image setting scale software (TPS-Dig, version 2.12; Rohlf 2008). Daily notochord changes of larvae in the experimental groups were quantified nearest $\pm 0.001 \mathrm{~mm}$ sensitivity.

Larval sampling and extraction of nucleic acids and protein

To examine changes of RNA/DNA ratio and protein contents, larvae were sampled on every day from the firstfeeding day $(n=8-15)$. After anesthetizing larvae with benzocaine ( $25 \mathrm{mg} / \mathrm{L}$; Sigma, MO, USA), notochord length (NL) of larvae was measured as explained above. For each sample, 6-12 individuals were marked and placed individually in 0.5 -mL polypropylene PCR tubes and then immediately frozen and stored at $-80{ }^{\circ} \mathrm{C}$ until analysis.

Fluorescence assay

DNA, RNA and protein from whole individual larvae were extracted according to the method described by Clemmesen (1994), with major modifications (Fig. 1). The total quantities of DNA, RNA and protein level were measured from individual larvae by using Qubit2.0 Fluorometer (Invitrogen, Life Technologies, Carlsbad, CA, USA) with DNA-, RNA- and protein-specific dye, respectively. According to the manufacturer's instructions, total DNA, RNA and protein were measured by Quant-iT dsDNA-BR, Quant-iT RNA-BR and protein assay kits (Invitrogen), respectively. Briefly, two assay tubes were set up for the standards and 1 tube for each sample. Qubit working solution was prepared by diluting the Qubit DNA reagent 1:200 in Qubit DNA buffer. About $200 \mu \mathrm{L}$ of working solution was prepared for each standard and sample. The assay tubes (0.5-mL clear PCR tubes) were prepared according to the following Table 2. Standards and samples were vortex for $2-3 \mathrm{~s}$ and incubated at room temperature for $2 \mathrm{~min}$. Fluorometer was calibrated with standards, and the samples were read. These procedures were repeated for RNA and protein quantification.

\section{Statistical analysis}

Same-aged larval groups were compared. Data with both normal distribution and equal variance were compared by analysis of covariance (ANCOVA), whereas data without equal variance or normal distribution were compared by Mann-Whitney $U$ test (SigmaPlot 11.0, Systat Software Inc., San Jose, CA, USA). NS illustrates "not significant", $* P<0.05$ and $* * P<0.01$. Survival rate of larvae was analyzed by Kaplan-Meier survival and failure time analysis tests (KMSFTAT), and when significant differences were found $(P<0.05)$, comparisons among means were made with a Cox-Mantel test (Statistica, Statsoft Inc., Tulsa, Oklahoma, USA). All data sets were presented as Mean \pm SD.

Table 1 Experimental feeding regimes [fed control, fed from the first-feeding day (FC), fed after being starved for 1 day from the first-feeding day (1 DS), starved for 2 days (2 DS), starved for 3 days (3 DS), unfed control (UC)] of horse mackerel larvae

\begin{tabular}{|c|c|c|c|c|c|}
\hline \multirow[t]{2}{*}{ Experiment } & \multicolumn{5}{|c|}{ Feeding regimes and number of larvae } \\
\hline & $\mathrm{FC}$ & $1 \mathrm{DF}$ & 2DF & 3DF & $\mathrm{UC}$ \\
\hline Survival & 100 , triplicate & 100 , triplicate & 100 , triplicate & 100 , triplicate & 100, triplicate \\
\hline Notochord & $\geq 300$ & $\geq 250$ & $\geq 200$ & $\geq 150$ & $\geq 200$ \\
\hline Nucleic acids and protein & $\geq 300$ & $\geq 250$ & $\geq 200$ & $\geq 150$ & $\geq 200$ \\
\hline
\end{tabular}


Fig. 1 Flowchart of DNA, RNA and protein determination the procedure
Add 2-3 glassbeads for disrupting tissue into stocked $0.5 \mathrm{ml}$ of eppendorf containing single larva and $200 \mu \mathrm{l}$ Tris-SDS buffer; Strong vortexing for $15 \mathrm{~min}$

\section{更}

Centrifuge for $10 \mathrm{~min}$ at $4^{\circ} \mathrm{C}, 8000 \times \mathrm{g}$, take $20 \mu \mathrm{l}$ from top layer and transfer into a new eppendorf for protein detection and hold at $-20^{\circ} \mathrm{C}$ until analvze

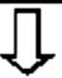

Add $180 \mu \mathrm{l}$ phenol and $180 \mu \mathrm{l}$ Chloroform/Isoamylalcohol (24:1), vortex for $5 \mathrm{~min}$

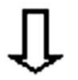

Centrifuge at $4^{\circ} \mathrm{C}, 3800 \times \mathrm{g}$ for $10 \mathrm{~min}$

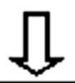

Take top layer (nucleic acid phase) and transfer a new eppendorf, add $180 \mu \mathrm{l}$ Chlor oform/soamylakohol, vorte $x$ for $5 \mathrm{~min}$

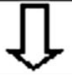

Centrifuge at $4^{\circ} \mathrm{C}, 3800 \times \mathrm{g}$ for $5 \mathrm{~min}$

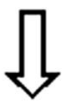

Use top layer for RNA, DNA and the stocked protein sample for prote in analyze, following the manufacturer's instructions by Qubit Fluorometer
Table 2 Preparation of standards and the samples for Qubit Fluorometer

\begin{tabular}{lll}
\hline Volume & Standards $(\mu \mathrm{L})$ & Samples $(\mu \mathrm{L})$ \\
\hline Working solution (from kit) & 190 & 180 \\
Standard (from kit) & 10 & - \\
Sample & - & 20 \\
Total in each assay tube & 200 & 200 \\
\hline
\end{tabular}

\section{Results}

\section{Starvation tolerance}

Eye pigmentation and mouth opening occurred on the third day after hatching. All larvae in UC group died on day 8 , whereas FC group had $61 \%$ survival rate. The other 1,2 and 3 days delayed groups had 30,12 and $6 \%$ survival rate, respectively (Fig. 2).

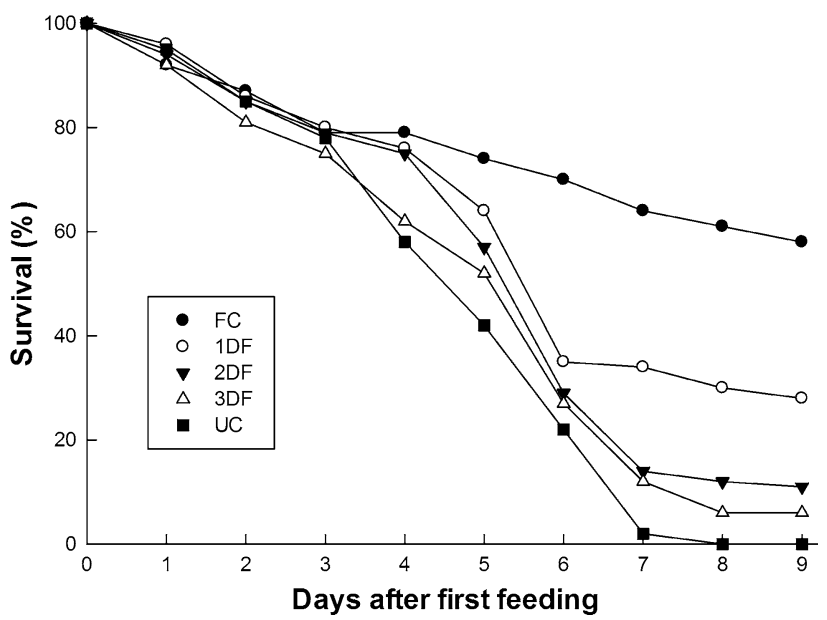

Fig. 2 Mean percent survival (MPS) of T. mediterraneus larvae fed after being starved for (open circle) 1 day from the first-feeding day, (filled inverter triangle) starved for 2 days, (triangle) starved for 3 days, (filled square) unfed control and fed control (filled circle) up to nine days 


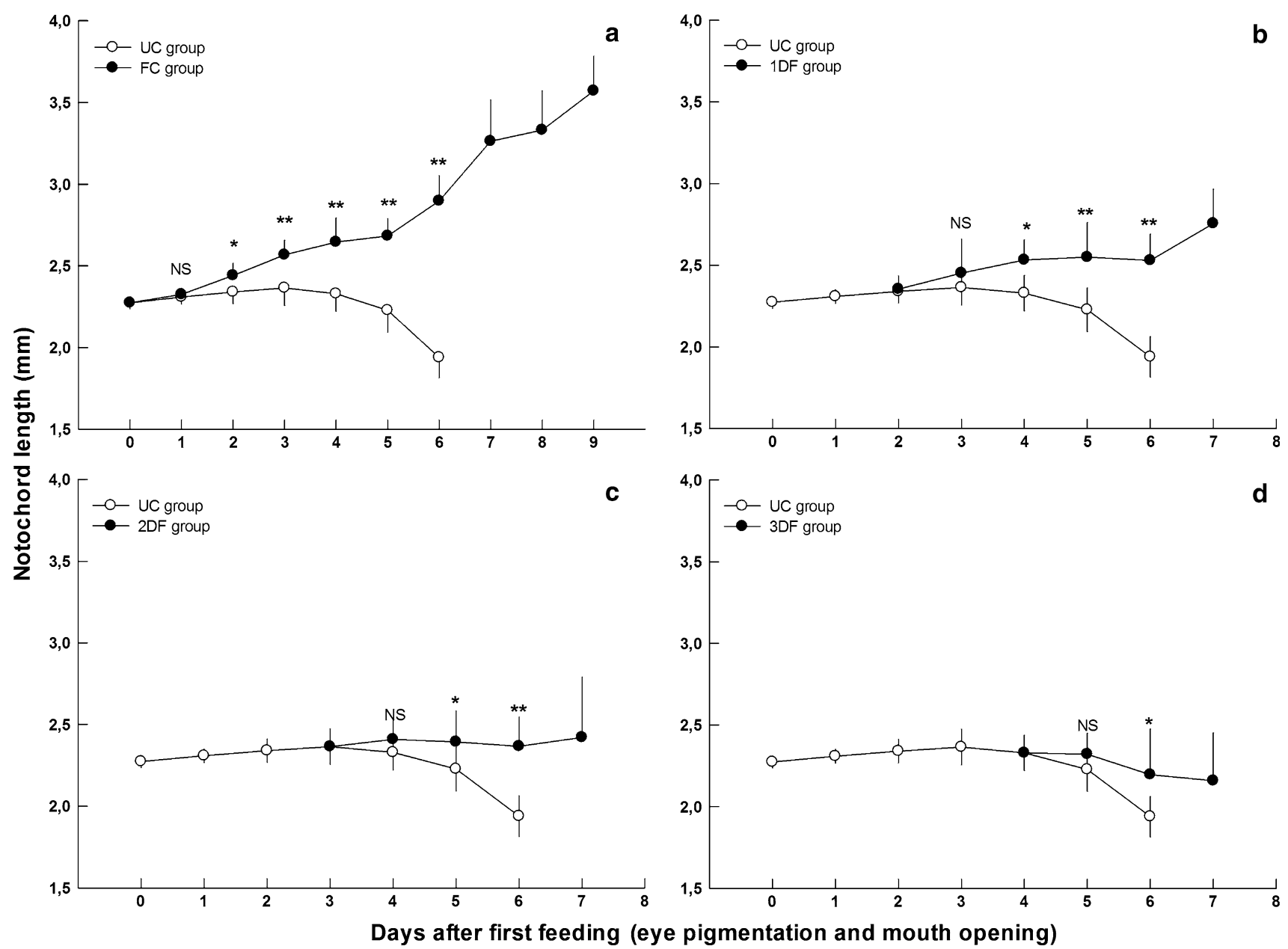

Fig. 3 Comparative notochord growth of T. mediterraneus of unfed control larvae (open circle) against the other fed groups (filled circle); fed control (FC), larvae fed after being starved for 1 day (1DF) from the first-feeding day, starved for 2 days (2DF), starved for 3 days

\section{Growth}

Newly hatched larvae had a mean notochord length of $2.27 \pm 0.04 \mathrm{~mm}$ and reached $2.35 \pm 0.08 \mathrm{~mm}$ on day 3 when eye pigmentation occurred, owing to maternal food source. Larvae in FC reached $3.57 \pm 0.21 \mathrm{~mm}$ while those in UC decreased to $1.93 \pm 0.12 \mathrm{~mm}$ by $8 \mathrm{DAH}$ (day after hatching). Compared to FC group, notochord lengths of delayed fed groups varied significantly (Fig. 3) $(P<0.05)$.

\section{Changes in RNA/DNA ratio}

The mean RNA/DNA ratio on day 0 was $1.73 \pm 0.19$. The ratio increased to $2.16 \pm 0.20$ on day 9 in $\mathrm{FC}$, while the mean RNA/DNA ratio of UC decreased progressively after day 0 and became $0.46 \pm 0.08$ on day 5 . The ratios of FC at the same ages, except for day 1, were significantly higher than those of $\mathrm{UC}(P<0.05)$. Larvae in $1 \mathrm{DF}$ group could
(3DF). Error bars indicate \pm SD. Significant differences between experimental groups of the same age. (NS not significant, ${ }^{*} P<0.05$; $* * P<0.01)$

intake live feed easily thereafter. Mean RNA content per larva was $0.342 \pm 0.032 \mu \mathrm{g}$ on day 0 and reached to $1.529 \pm 0.374 \mu \mathrm{g}$ in the FC group on day 9. Larvae in UC were $0.124 \pm 0.016 \mu \mathrm{g} / \mathrm{larva}$ on day 5 . Mean DNA content per larva was $0.199 \pm 0.014 \mu \mathrm{g}$ on day 0 and reached to $0.717 \pm 0.067 \mu \mathrm{g}$ in FC group on day 9 , while those in UC were $0.198 \pm 0.019 \mu \mathrm{g}$ per larva on day 5 (Fig. 4). There was a significant allometric relationship found between RNA and DNA content per larva and larval age (Fig. 5) (0-9 day, $P<0.01)$.

Protein content and growth in protein

Mean protein content was $5.15 \pm 0.52 \mu \mathrm{g} /$ larva on day 0 . Mean protein content in UC gradually decreased and became $1.30 \pm 0.64 \mu \mathrm{g} /$ larva on day 4 , while in $\mathrm{FC}$ became $28.59 \pm 6.06 \mu \mathrm{g} /$ larva on day 9. The highest growth in protein was detected in $\mathrm{FC}$ on day 7 , significant 

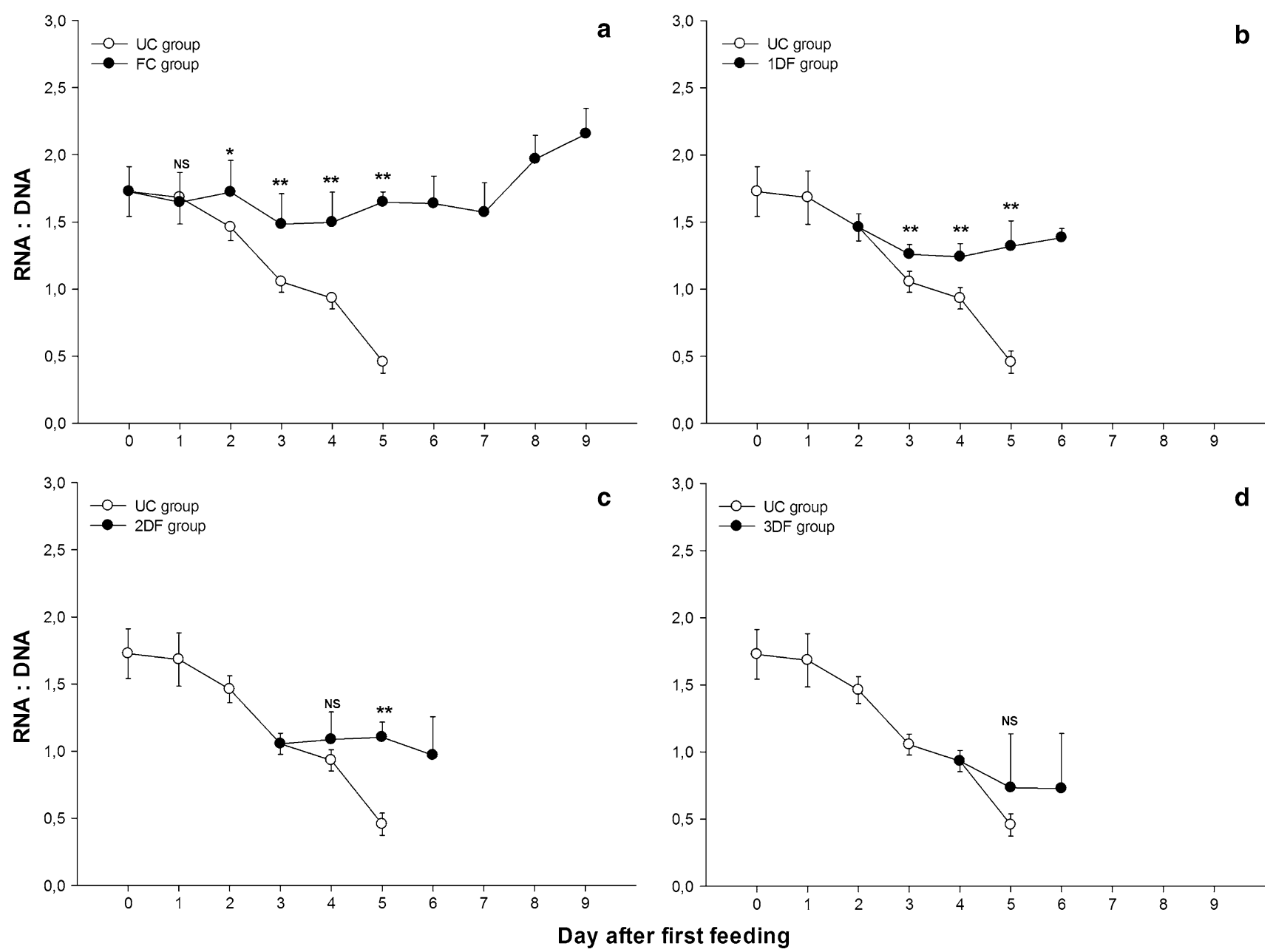

Fig. 4 Comparative mean RNA/DNA ratios of unfed control of $T$. mediterraneus larvae (open circle) against the other experimental fed groups (filled circle); fed control (FC), larvae fed after being starved for 1 day (1DF) from the first-feeding day, starved for 2 days (2DF),

differences between both groups on day 3 and 4 were figured (Fig. 6).

RNA/DNA in field-caught larvae

A total of 76 wild-type horse mackerel larvae were sampled at different sizes. Approximately $10 \%$ of the fieldcaught larvae were at point of no return (PNR) (Fig. 7).

\section{Discussion}

Horse mackerel is one of the most common fish species in Black Sea. It has commercial value and is considered to be overfished. Although there are no reliable statistics on $T$. mediterraneus landings in the Black Sea, rough estimates of the annual catch tend to fluctuate and decline in recent years (Yankova et al. 2010; TUIK 2010). Spawning season usually starved for 3 days (3DF). Error bars indicate \pm SD. Significant differences between experimental groups of the same age (NS not significant, $* P<0.05 ; * * P<0.01)$

ranges from June to September (Russell 1976) depending on seasonal patterns. Eggs are released into coastal areas, which are known to be rich in planktonic organisms. Although there are couple of ichthyoplankton studies available in the literature dealing with horse mackerel (Satilmis et al. 2003; Somarakis et al. 2011), there is no information on the hatching, larval stages and rearing of horse mackerel. In the current study, RNA/DNA criterion was derived from the experiment, and thereafter, the field-caught larvae were assessed according to experimental results.

Approximately, sixty percent hatching success was achieved from the collected genoblast eggs in the present study. Nevertheless, there is no information available in the literature on hatching of wild-collected eggs of horse mackerel. Sampled eggs had mean 0.78-0.90 mm diameter, single oil globule and buoyant, and they all hatched within 10-15 h after sampling, but it was unknown when the eggs had been fertilized. 


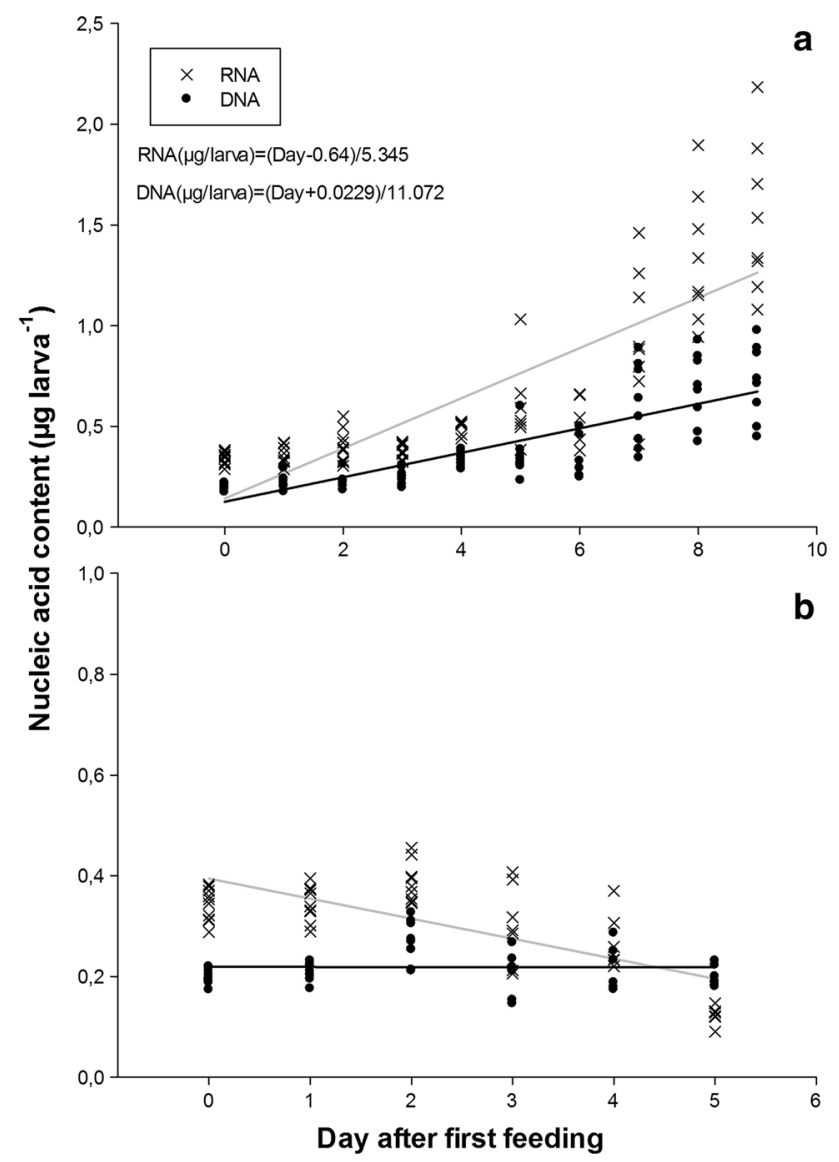

Fig. 5 Changes of total RNA and DNA quantity of fed control (a) and unfed control (b) of T. mediterraneus larvae. Allometric relationships between larval horse mackerel age as day and RNA content $\left(R^{2}=0.666 ; P<0.01\right)$ and DNA content $\left(R^{2}=0.672\right.$; $P<0.01)(\mu \mathrm{g} /$ larva $)$

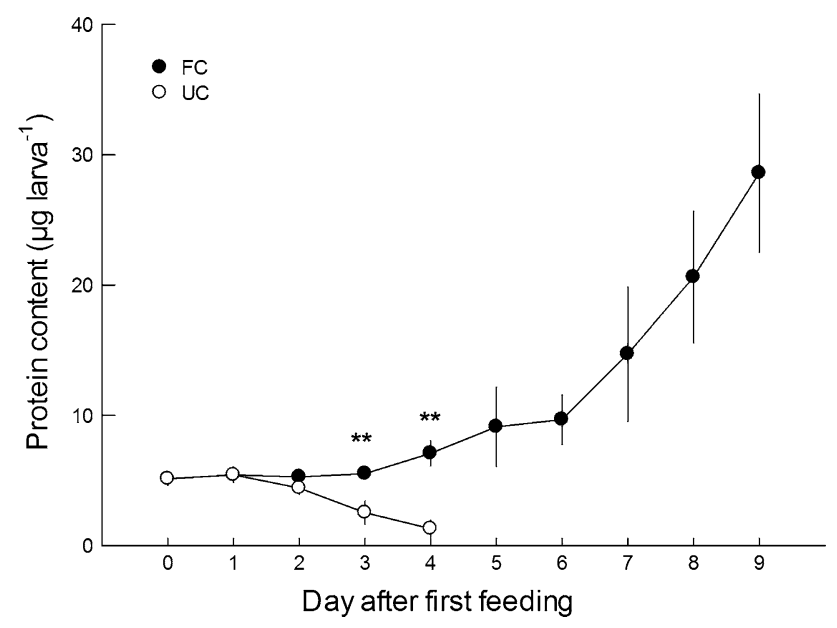

Fig. 6 Trachurus mediterraneus. Mean protein content of fed (filled circle) and unfed control (open circle) larvae. Error bars indicate \pm SD. **Significant differences between both groups of the same age. $(P<0.01)$

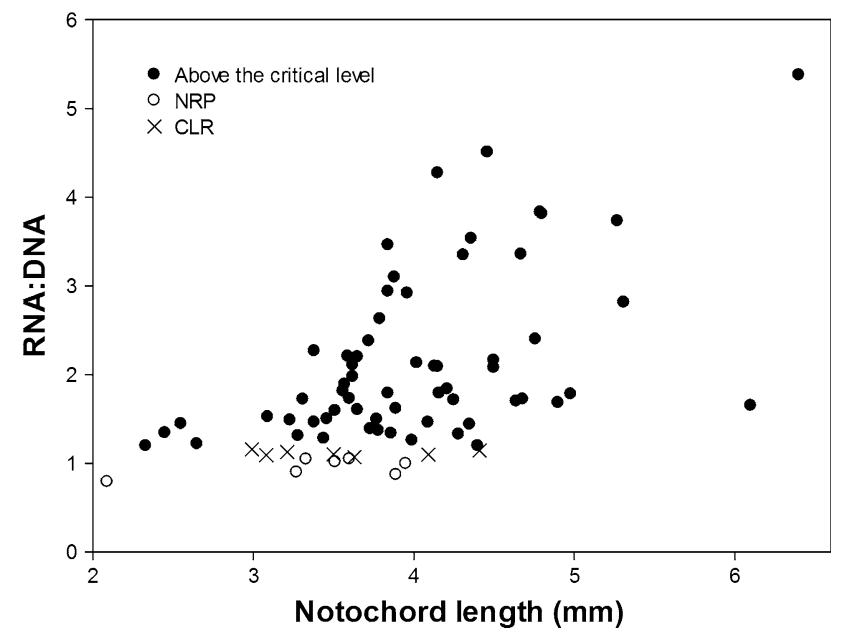

Fig. 7 Trachurus mediterraneus. RNA/DNA ratios of field-caught larvae, above the critical starving level (filled circle), PNR; no return point (open circle), CLR critical level range (X)

In general, marine fish larvae switch to external feeding when some anatomical features occur such as the opening of the mouth and anus or the pigmentation of eyes (Tanaka et al. 1995; Yufera and Darias 2007). Therefore, the firstfeeding day (eye pigmentation as an index) for starvation experiments was regarded as 0 to compare with similar experiments done by Kono et al. (2003). In the current study, eye pigmentation occurred between 52 and $70 \mathrm{~h}$ and this period varied depending on water temperature ranged between 25 and $21{ }^{\circ} \mathrm{C}$, respectively. Eye pigmentation and mouth opening stage were observed under microscopy on the third day after hatching. For Japanese anchovy, pigmentation of eyes and feeding were indicated to start 2 days after hatching (Kono et al. 2003).

It is monitored that larvae remained suspended close to the water surface immediately after hatching. After remaining there for 20-28 h, they swam downward and stayed at the bottom without moving more actively until they consumed maternal-origin reserves (yolk sac and oil globule). In the preliminary studies, the highest mortality was recorded during the suspending of larvae close to the water surface. This kind of deaths was reported as surface tension-related deaths that can be reduced by adding chicken egg white in the water (Yandi and Altinok 2012). Because of that, chicken egg white was added into rearing waters for a final concentration of $60 \mu \mathrm{L} / \mathrm{L}$, and this application was continued during incubation and up to 3 DAH. Larvae rely on their caudal fins in order to attain live feed. It was observed that larvae with caudal fin deformity had disadvantage to receive live feed and died in a short time. Therefore, this kind of abnormal larvae was eliminated from the experiments. 
All larvae in unfed control group died on day 8, whereas fed control group had $61 \%$ survival. The other 1,2 and 3 days delayed groups had an average survival of 30,12 and $6 \%$, respectively. These results indicated that horse mackerel larvae would die unless they were fed within the first 3 days after the first-feeding day. Even a single day of starvation leads to a $50 \%$ decrease in survival between day 5 and 6. After 2 or 3 days of starvation, larval survival decreased until day 7. Most of the newly hatched marine fish larvae have unpigmented eyes and a rudimentary digestive system, including an incomplete mouth opening. Development in anatomical, physiological and digestive system takes place in the following hours and days (Yufera and Darias 2007), and it seems to be the case that the larvae face an energy-consuming developmental stage from the fifth day onward. A possible explanation for the increased mortality might be that larvae need to store sufficient energy before being able to cope with it.

Testing full starvation over several days, or even a single day, in an ecological context should be relevant. The match-mismatch hypothesis (Cushing 1972, 1990) built on the "critical period" starvation theory of Hjort (1914). Larvae would die directly if there was a mismatch between larva and prey thereafter. Starving larvae are more vulnerable to predation, so while they may not die from starvation directly, they are weaker, have slow growth and may take risky behavior that increases their predation risk. Abundance of prey is known to be patchy in the environment, which makes it likely for emerging, first-feeding larvae to be located outside of a patch for a certain period of time. Assessing different scenarios of initial starvation period thus makes sense in an ecological point of view. Moreover, a recent study by Chinaa and Holzman (2014) provided evidence that emerging larvae have low feeding ability in the sea due to hydrodynamic forces (what they refer to as "hydrodynamic starvation"). Quantifying firstfeeding starvation resilience is necessary to determine to what extent this critical stage constitutes a recruitment bottleneck in a given species.

The survival rate for Thunnus orientalis larvae was estimated $10-50 \%$ on day 3 after 1 day of starved conditions at $25^{\circ} \mathrm{C}$ (Tanaka et al. 2008). For Japanese anchovy, it was reported that all larvae had died by day 5 in unfed conditions and $0 \%$ survival at 1 day starvation (and food supplied thereafter) at $20{ }^{\circ} \mathrm{C}$ (Kono et al. 2003). The present study showed that horse mackerel larvae had higher survival rates and more tolerance to starvation than anchovy larvae.

In the present study, larvae were fed with Brachionus cultured with Nannochloropsis. Both species are known to provide a very low food quality for marine fish larvae due to a very low content of essential fatty acids. Several studies have shown that larval growth as well as survival is affected not only by food quantity, but also food quality (St. John et al. 2001; Copeman and Laurel 2010; Paulsen et al. 2014). Survival rates and also RNA/DNA ratios might have been higher with a higher food quality. Since present study focused on analyzing critical RNA/DNA ratios and not the effect of prey quantity on the RNA/DNA ratio, our results should nevertheless be valid. On the other hand, similar to our findings, Meyer et al. (2012) found that the mean biochemical condition of larvae decreased exponentially with starvation time, regardless of initial condition and endogenous yolk reserves.

Newly hatched larvae of horse mackerel had mean notochord length $2.27 \pm 0.04 \mathrm{~mm}$ and reached to $2.35 \pm 0.08$ on day 3 when eye pigmentation occurred, owing to maternal food source. Total length of the larvae in FC reached to $3.57 \pm 0.21 \mathrm{~mm}$, while those in UC was $1.93 \pm 0.12 \mathrm{~mm}$. Significant growth delay in standard length and notochord of 1 day starved larval Pacific bluefin tuna (Tanaka et al. 2008) and Japanese anchovy (Kono et al. 2003) were observed in previous studies.

The critical value of the RNA/DNA ratio for survival is species specific (Tanaka et al. 2008). The critical value is 1.3 for Sardina pilchardus (Chicharo et al. 1998), approximately 1.0 for Engraulis japonicus at 20 and $25{ }^{\circ} \mathrm{C}$ (Kono et al. 2003). Since these species are small pelagic fish species, the critical value would be expected to relatively similar to horse mackerel. The critical values for some species are as follows; 4.1 for cod and haddock (Lough et al. 1996), 2.0 for striped bass Morone saxatilis (Martin et al. 1985) and 1.08-5.36 for Japanese flounder Paralichthys olivaceus (Gwak and Tanaka 2001). In the current study, the mean RNA/DNA ratio on day 0 was $1.73 \pm 0.19$. The ratio increased in $\mathrm{FC}$ to $2.16 \pm 0.20$ on day 9, while the mean RNA/DNA ratio of UC became $0.46 \pm 0.08$ on day 5 .

RNA/DNA indicating PNR of 3 DF larvae was $1.05 \pm 0.08$. This value was accepted as the critical RNA/ DNA value indicating PNR for horse mackerel, which seems to be in a range of other small pelagic fishes such as sardine and anchovy and PNR occurred following the third day after first-feeding day. It was reported that the PNR was between 1 and 2 days after the first-feeding day at 20-25 ${ }^{\circ} \mathrm{C}$ for Japanese anchovy (Kono et al. 2003). Larval horse mackerel appeared to be more tolerant to starvation than larval Japanese anchovy. A significant allometric relationship was found between RNA and DNA content per larva and larval age. This result showed that nucleic acids increased under feeding conditions. Due to the fact that larvae suffer mortality of about $50 \%$ between day 5 and 6 , it should be considered that, additionally to the PNR value of 1.05 , a critical RNA/DNA ratio of something like 1.35 or 1.4 (1 DF group) exists. This is supported by the increasing trend in larval RNA/DNA in DF 1 group. Below 
this value, the probability of larval death due to starvation increases strongly.

Temperature influences physiological processes and affects RNA/DNA ratios and the somatic growth rate in a variety of larval fish species (Buckley 1984; Buckley et al. 1984, 1990; Clemmesen 1996; Folkvord et al. 1996; Garcia et al. 1998; Kono et al. 2003). In the current study, the highest number of eggs was sampled in July where the surface water temperature was around $20-22{ }^{\circ} \mathrm{C}$. A total of 76 wild-type horse mackerel larvae were sampled at different sizes. Approximately $10 \%$ of the larvae were starving and would not have been capable of complete recovery at $21{ }^{\circ} \mathrm{C}$. Percentage of starving larvae in the field was estimated as 5-80\% in the smaller length classes and 4-6\% in the higher ones for Atlantic anchovy E. anchoita (Clemmesen et al. 1997), $5.5 \%$ for Japanese flounder (Gwak and Tanaka 2001) and $0.0-4.8 \%$ for sardine $S$. pilchardus (Chicharo et al. 1998, Chícharo et al. 2003). In the current study, limited number of larvae (76) was sampled, so it is difficult to make definite conclusions for the nutritional status of natural larval horse mackerel stocks. The starving larvae are likely to be picked out of the system by predators (Takasuka et al. 2003); therefore, it might be that only $10 \%$ of field-caught starving larvae are an indicator of selective pressure caused by biotic and abiotic factors.

Several indices have been developed to evaluate the condition in marine fish larvae. The accuracy, availability, sustainability, comparability, the analysis times and the costs were investigated in detail (Chicharo and Chicharo 2008). Because of increasing sensitivity and reliability of the analysis, the nucleic acid-based indices have been widely used in many marine organisms (Caldarone et al. 2006). Among them, the ratio of RNA/DNA is the most commonly used index to determine the nutritional status of marine fish larvae (Meyer et al. 2012). The amount of RNA and DNA were determined by spectrophotometer in previous studies. In this respect, the first protocol was created by Clemmesen (1993). Then, she developed the earlier protocol in order to overcome the problems and compared both protocols (Clemmesen 1994). In later years, the protocols used in different studies conducted based on modifying in certain stages of Clemmesen's (1994) protocol. Larvae must be completely disrupted during the extraction process; otherwise, quantities of nucleic acid per larva may lead to erroneous results, but it does not affect the RNA/ DNA ratio.

Larval tissue disruptions are made using glass beads (Clemmesen 1993, 1994; Gwak 2002), pestle pipette (Kono et al. 2003), cold sonication (Fonseca et al. 2006; Hook et al. 2008) or homogenizer (Mercaldo-Allen et al. 2006). Each of these disruption methods has some advantages and disadvantages depending on the situation. Pestle pipette may cause erroneous results for amount of nucleic acid per larva since a portion of fragmented larvae infects pestle apparatus. On the other hand, homogenizer is not suitable for early larvae; however, it is more suitable for tissue samples taken from larger larvae. In the present study, sonicator was compared to glass beads to homogenize larvae (unpublished data). Lower RNA values were obtained when larva disrupted with sonicator compared glass beads (unpublished data). Sonicator increases sample temperature over time, and probably, an increase in temperature is the reason for the RNA degradation and the increased temperature leads to RNA degradation. For this reason, glass beads were used to homogenize larvae in the present study.

In terms of fluorometric detection, similar methods have been used in the majority of the researchers (Chicharo et al. 2001, 2007; Gwak et al. 2003; Kono et al. 2003; Caldarone et al. 2006; Fonseca et al. 2006; Mercaldo-Allen et al. 2006; Hook et al. 2008; Tanaka et al. 2008; Vinagre et al. 2008). According to these methods, after extracting DNA and RNA, aliquot was separated in two volumes. One part was used for detecting total nucleic acids (RNA + DNA), while the other part was used to detect DNA after adding RNAse. In the current method, a new extraction protocol and a new fluorometric method were developed and neither RNAse nor DNAse was added into samples. Protocol developed in the present study takes shorter time, and smaller quantities of RNA, DNA and protein can be detected compared to published methods (unpublished data). Additionally, compared to published methods, present method has the higher sensitivity, which is especially important for analyzing very small larvae, while for the analysis of bigger larvae, the classical approach remains suitable. At the same time, shorter processing time may mean more accurate result owing to the risk of the quick degradation of RNA.

The Qubit assays were developed using proprietary dyes derived from PicoGreen ${ }^{\mathrm{TM}}$, SYBR-Green ${ }^{\mathrm{TM}}$ and RiboGreen $^{\mathrm{TM}}$ (Molecular Probes, Eugene, OR) that offer selective quantitation of DNA, RNA or protein based upon different binding affinities and the quantitation sensitivities per assay (Mansfield et al. 1995; Ahn et al. 1996; Bolger et al. 1997; Jones et al. 1998; Murakami and McCaman 1999; Guillo et al. 2006). The dyes derived from PicoGreen, RiboGreen and SYBR-Green, used in the current study, were much more selective and sensitive than that of ethidium bromide used in previously published methods (Ahn et al. 1996; Jones et al. 1998; Guillo et al. 2006).

Although most studies focus on morphological and ecological aspects of T. mediterraneus, the larval rearing and tolerance to starvation remain unknown. In the present study, an index based on the RNA/DNA ratio has been developed for horse mackerel. The current fluorometric method for detecting RNA, DNA and protein from 
individual larvae seems sensitive. Therefore, RNA/DNA ratios found in the present study make it possible to assess whether horse mackerel larvae caught in the field are starving or not.

Acknowledgments This study was supported by grant from the TUBITAK (Project No.: 110O050).

\section{References}

Ahn SJ, Costa J, Emanuel JR (1996) PicoGreen quantitation of DNA: effective evaluation of samples pre- or post-PCR. Nucleic Acids Res 24(13):2623-2625. doi:10.1093/nar/24.13.2623

Alemany IAC (2003) Condition indices and their relationship with environmental factors in fish larvae. Thesis Doctoral, Universitat De Barcelona

Amara R, Galois R (2004) Nutritional condition of metamorphosing sole: spatial and temporal analyses. J Fish Biol 64:72-88. doi:10. 1046/j.1095-8649.2003.00284.x

Bolger R, Lenoch F, Allen E, Meiklejohn B, Burke T (1997) Fluorescent dye assay for detection of DNA in recombinant protein products. Biotechniques 23:532-536

Buckley LJ (1984) RNA-DNA ratio-an index of larval fish growth in the sea. Mar Biol 80:291-298. doi:10.1007/Bf00392824

Buckley LJ, Turner SI, Halavik TA, Smigielski AS, Drew SM, Laurence GC (1984) Effects of temperature and food availability on growth, survival, and RNA-DNA ratio of larval sand lance (Ammodytes-Americanus). Mar Ecol Prog Ser 15:91-97

Buckley LJ, Smigielski AS, Halavik TA, Laurence GC (1990) Effects of water temperature on size and biochemical-composition of winter flounder Pseudopleuronectes-americanus at hatching and feeding initiation. Fish B NOAA 88:419-428

Caldarone EM, Clemmesen CM, Berdalet E, Miller TJ, Folkvord A, Holt GJ, Olivar MP, Suthers IM (2006) Intercalibration of four spectrofluorometric protocols for measuring RNA/DNA ratios in larval and juvenile fish. Limnol Oceanogr Methods 4:153-163

Chicharo MA, Chicharo L (2008) RNA : DNA ratio and other nucleic acid derived indices in marine ecology. Int $\mathrm{J}$ Mol Sci 9:1453-1471. doi:10.3390/Ijms9081453

Chicharo MA, Chicharo L, Valdes L, Lopez-Jamar E, Re P (1998) Does the nutritional condition limit survival potential of sardine Sardina pilchardus (Walbaum, 1792) larvae off the north coast of Spain? RNA/DNA ratios and their variability. Fish Res 39:43-54

Chicharo LMZ, Chicharo MA, Alves F, Amaral A, Pereira A, Regala $\mathrm{J}$ (2001) Diel variation of the RNA/DNA ratios in Crassostrea angulata (Lamarck) and Ruditapes decussatus (Linnaeus 1758) (Mollusca: Bivalvia). J Exp Mar Biol Ecol 259:121-129. doi:10. 1016/S0022-0981(01)00229-5

Chícharo MA, Chícharo L, Amaral A, Condinho S, Gaspar M (2003) Chronic effects of dredging-induced stress on the clam (Spisula solida): nucleic acid and lipid composition. Fish Res 63:447-452

Chicharo MA, Amaral A, Morais P, Chicharo L (2007) Effect of sex on ratios and concentrations of DNA and RNA in three marine species. Mar Ecol Prog Ser 332:241-245. doi:10.3354/Meps332241

Chinaa V, Holzman R (2014) Hydrodynamic starvation in firstfeeding larval fishes. Proc Natl Acad Sci USA 111:8083-8088

Clemmesen C (1993) Improvements in the fluorometric-determination of the RNA and DNA content of individual marine fish larvae. Mar Ecol Prog Ser 100:177-183. doi:10.3354/Meps100177

Clemmesen C (1994) The effect of food availability, age or size on the RNA/DNA ratio of individually measured herring larvaelaboratory calibration. Mar Biol 118:377-382. doi:10.1007/ Bf00350294
Clemmesen C (1996) Importance and limits of RNA/DNA ratios as a measure of nutritional condition in fish larvae. In: Watanabe $\mathrm{Y}$, Yamashita Y, Oozeki Y (eds) Survival strategies in early life stages of marine resources. Balkema, Rotterdam, pp 67-82

Clemmesen C, Sanchez R, Wongtschowski C (1997) A regional comparison of the nutritional condition of SW Atlantic anchovy larvae, Engraulisanchoita, based on RNA/DNA ratios. Arch Fish Mar Res 45(1):17-43

Copeman LA, Laurel BJ (2010) Experimental evidence of fatty acid limited growth and survival in Pacific cod larvae. Mar Ecol Prog Ser 412:259-272. doi:10.3354/meps08661

Cury P, Roy C (1989) Optimal environmental window and pelagic fish recruitment success in upwelling areas. Can J Fish Aquat Sci 46:670-680

Cushing DH (1972) The production cycle and the numbers of marine fish. Symp Zool Soc Lond 29:213-232

Cushing D (1974) The natural regulation in fish populations. In: Harden Jones FR (ed) Sea fisheries research. Elek Science, London, pp 399-412

Cushing DH (1990) Plankton production and year-class strength in fish populations: an update of the match/mismatch hypothesis. Adv Mar Biol 26:249-294

Dekhnik TV (1973) Ikhtioplankton Chernogo moria. Nauk. dumka, Kiev

Folkvord A, Ystanes L, Johannessen A, Moksness E (1996) RNA/ DNA ratios and growth of herring (Clupea harengus) larvae reared in mesocosms. Mar Biol 126:591-602. doi:10.1007/ Bf00351326

Fonseca VF, Vinagre C, Cabral HN (2006) Growth variability of juvenile soles Soleasolea and Solea senegalensis, and comparison with RNA/DNA ratios in the Tagus estuary, Portugal. J Fish Biol 68:1551-1562. doi:10.1111/j.1095-8649.2006.01042.x

Garcia A, Cortes D, Ramirez T (1998) Daily larval growth and RNA and DNA content of the NW Mediterranean anchovy Engraulis encrasicolus and their relations to the environment. Mar Ecol Prog Ser 166:237-245. doi:10.3354/Meps166237

Guillo C, Ferrance JP, Landers JP (2006) Use of a capillary electrophoresis instrument with laser-induced fluorescence detection for DNA quantitation-comparison of YO-PRO-1 and PicoGreen assays. J Chromatogr A 1113(1-2):239-243. doi:10.1016/j.chroma.2006.01.011

Gwak WS (2002) Diel variation in RNA/DNA ratios of Japanese flounder Paralichthys olivaceus. J World Aquaculture Soc 33:501-505. doi:10.1111/j.1749-7345.2002.tb00030.x

Gwak WS, Tanaka M (2001) Developmental change in RNA: DNA ratios of fed and starved laboratory-reared Japanese flounder larvae and juveniles, and its application to assessment of nutritional condition for wild fish. J Fish Biol 59:902-915. doi:10.1006/jfbi.2001.1703

Gwak WS, Tsusaki T, Tanaka M (2003) Nutritional condition, as evaluated by RNA/DNA ratios, of hatchery-reared Japanese flounder from hatch to release. Aquaculture 219:503-514. doi:10.1016/S0044-8486(02)00651-8

Hjort J (1914) Fluctuations in the great fisheries of Northern Europe. Rapp Int Conseil Pour L'Exploration de la Mer 20:1-228

Hook TO, Gorokhova E, Hansson S (2008) RNA: DNA ratios of Baltic Sea herring larvae and copepods in embayment and open sea habitats. Estuar Coast Shelf Sci 76:29-35. doi:10.1016/j.ecss. 2007.06.012

Houde ED (1978) Critical food concentrations for larvae of three species of subtropical marine fishes. Bull Mar Sci 28:395-411

Jones LJ, Yue ST, Cheung CY, Singer VL (1998) RNA quantitation by fluorescence-based solution assay: RiboGreen reagent characterization. Anal Biochem 265(2):368-374. doi:10.1006/abio.1998.2914

Kono N, Tsukamoto Y, Zenitani H (2003) RNA/DNA ratio for diagnosis of the nutritional condition of Japanese anchovy 
Engraulis japonicus larvae during the first-feeding stage. Fish Sci 69:1096-1102. doi:10.1111/j.0919-9268.2003.00733.x

Lasker R (1978) The relationship between oceanographic conditions and larval anchovy food in the California current: identification of factors contributing to recruitment failure. Rapp P-vRéun Cons int Explor Mer 173:212-230

Lough RG, Caldarone EM, Rotunno TK, Broughton EA, Burns BR, Buckley LJ (1996) Vertical distribution of cod and haddock eggs and larvae, feeding and condition in stratified and mixed waters on southern Georges Bank, May 1992. Deep Sea Res I 43:1875-1904. doi:10.1016/S0967-0645(96)00053-7

Mansfield ES, Worley JM, Mckenzie SE, Surrey S, Rappaport E, Fortina P (1995) Nucleic-acid detection using nonradioactive labeling methods. Mol Cell Probe 9(3):145-156. doi:10.1006/ mcpr.1995.0023

Martin FD, Wright DA, Means JC, Setzlerhamilton EM (1985) Importance of food-supply to nutritional state of larval striped bass in the Potomac River estuary. Trans Am Fish Soc 114:137-145. doi:10.1577/1548-8659(1985)114<137:Iofstn $>2$. $0 . \mathrm{Co} ; 2$

Mercaldo-Allen R, Kuropat C, Caldarone EM (2006) A model to estimate growth in young-of-the-year tautog, Tautoga onitis, based on RNA/DNA ratio and seawater temperature. J Exp Mar Biol Ecol 329:187-195. doi:10.1016/j.jembe.2005.08.015

Meyer S, Caldarone E, Chícharo MA, Clemmesen C, Faria A, Folkvord A, Holt G, Høie H, Malzahn A, Moran D, Petereit C, Støttrup J, Peck M (2012) On the edge of death: rates of decline and lower thresholds of biochemical condition food-deprived marine fish larvae and juveniles. J Mar Sci 93:11-24. doi:10. 1016/j.jmarsys.2011.09.010

Murakami P, McCaman MT (1999) Quantitation of adenovirus DNA and virus particles with the PicoGreen fluorescent dye. Anal Biochem 274(2):283-288. doi:10.1006/abio.1999.4282

Nunn AD, Harvey JP, Cowx IG (2007) The food and feeding relationships of larval and $0+$ year juvenile fishes in lowland rivers and connected waterbodies. II. Prey selection and the influence of gape. J Fish Biol 70:743-757

Paulsen M, Clemmesen C, Malzahn AM (2014) Essential fatty acid (docosahexaenoic acid, DHA) availability affects growth of larval herring in the field. Mar Biol 161:239-244. doi:10.1007/ s00227-013-2313-6

Rohlf JF (2008) tpsDig version 2.12. Department of Ecology and Evolution. State University of New York, Stony Brook. http// life.bio.sunysb.edu/morph/-7 k. Accessed in 15 Aug 2012

Russell FSS (1976) The eggs and planktonic stages of British marine fishes. Academic Press, London

Satilmis HH, Gordina AD, Bat L, Bircan R, Culha M, Akbulut M, Kideys AE (2003) Seasonal distribution of fish eggs and larvae off sinop (the southern Black Sea) in 1999-2000. Acta Oecol 24:275-280. doi:10.1016/S1146-609x(03)00022-5

Sinclair M (1988) Marine populations: an essay on population regulation and speciation. University of Washington Press, Seattle

Somarakis S, Ramfos A, Palialexis A, Valavanis VD (2011) Contrasting multispecies patterns in larval fish production trace inter-annual variability in oceanographic conditions over the NE Aegean Sea continental shelf (Eastern Mediterranean). Hydrobiologia 670:275-287. doi:10.1007/s10750-011-0677-5

St John MA, Clemmesen C, Lund T, Koster T (2001) Diatom production in the marine environment: implications for larval fish growth and condition. ICES J Marine Sci 58:1106-1113

Takasuka A, Aoki I, Mitani I (2003) Evidence of growth-selective predation on larval Japanese anchovy Engraulis japonicus in Sagami Bay. Mar Ecol Prog Ser 252:223-238. doi:10.3354/ Meps252223

Tanaka M, Tanangonan JB, Tagawa M, deJesus EG, Nishida H, Isaka M, Kimura R, Hirano T (1995) Development of the pituitary, thyroid and interrenal glands and applications of endocrinology to the improved rearing of marine fish larvae. Aquaculture 135(1-3):111-126. doi:10.1016/0044-8486(95)01019-X

Tanaka Y, Satoh K, Yamada H, Takebe T, Nikaido H, Shiozawa S (2008) Assessment of the nutritional status of field-caught larval Pacific bluefin tuna by RNA/DNA ratio based on a starvation experiment of hatchery-reared fish. J Exp Mar Biol Ecol 354:56-64. doi:10.1016/j.jembe.2007.10.007

TUIK (2010) Annual report: the state of Turkish fisheries and aquaculture 2009. Turkish Statistic Board, Ankara

Vinagre C, Fonseca V, Maia A, Amara R, Cabral H (2008) Habitat specific growth rates and condition indices for the sympatric soles Solea solea (Linnaeus, 1758) and Solea senegalensis Kaup 1858, in the Tagus estuary, Portugal, based on otolith daily increments and RNA-DNA ratio. J Appl Ichthyol 24:163-169. doi:10.1111/j.1439-0426.2007.01048.x

Yandi I, Altinok I (2012) Prevention of surface death of horse mackerel (Trachurus mediterraneus) larvae by the addition of egg white and camphor grain to rearing water. Aquac Res 43:1065-1070. doi:10.1111/j.1365-2109.2011.02909.x

Yankova MH, Raykov VS, Gerdzhikov DB, Frateva PB (2010) Growth and length-weight relationships of the horse mackerel, Trachurus mediterraneus ponticus (Aleev, 1956), off the Bulgarian Black Sea coast. Turk J Zool 34:85-92. doi:10.3906/ Zoo-0811-10

Yufera M, Darias MJ (2007) The onset of exogenous feeding in marine fish larvae. Aquaculture 268(1-4):53-63. doi:10.1016/j. aquaculture.2007.04.050 